\title{
Character education values: is learning process in elementary school implement it?
}

\author{
Aci Pratiwi*, Darmiany, Heri Setiawan \\ Elementary School Teacher Education Study Program, FKIP, University of Mataram, Jl. \\ Majapahit No 62 Mataram, 83125, Indonesia \\ *Corresponding Author e-mail: acipratiwi03@gmail.com
}

Received: November 2021; Revised: November 2021; Published: December 2021

\begin{abstract}
This study aimed to determine the implementation of character education values at SDN 19 Rabangodu Utara, Bima City. The type of research used is mixed methods research with an exploratory design. This type of research combines qualitative and quantitative research. In this study, the researchers developed a questionnaire instrument and an observation sheet. Data collection techniques used in this study are observation, interviews (interviews), questionnaires (questionnaires), and documentation. The data analysis technique used descriptive data analysis techniques according to Miles and Huberman for qualitative data and descriptive statistical analysis for quantitative data. Based on the results of data analysis, the results of the study indicate that (1) The process of implementing character education values carried out at SDN 19 Rabangodu Utara, Bima City through self-development activities (routine activities, spontaneous activities, exemplary and conditioning) and integration in thematic learning ( Syllabus and lesson plans and the learning process); (2) The behavior of students in applying character values (religious, honest, diligent, disciplined, and caring/responsible) is in the sufficient category as many as 52 people $(61.17 \%)$; The rest in the good category as many as 18 people $(21.18 \%)$, and in the less category as many as 15 people (17.65\%); (3) Obstacles faced by schools in the process of implementing character education values include the lack of attention from some parents to students, the online habits of students who like to play gadgets and watch TV, and lack of room infrastructure at SDN 19 Rabangodu Utara, Bima City.
\end{abstract}

Keywords: Learning process, Character Education, elementary school

How to Cite: Pratiwi, A., Darmiany, D., \& Setiawan, H. (2021). Character education values: is learning process in elementary school implement it?. Prisma Sains : Jurnal Pengkajian Ilmu dan Pembelajaran Matematika dan IPA IKIP Mataram, 9(2), 267-279. doi:https://doi.org/10.33394/j-ps.v9i2.4374

https://doi.org/10.33394/j-ps.v9i2.4374

Copyright@ 2021, Pratiwi et al This is an open-access article under the CC-BY License. (c) (1)

\section{INTRODUCTION}

Indonesia is currently faced with the problem of weakening the nation's character (Anwar, 2018) The noble character, decency and religiosity that are maintained and become Indonesian culture so far feel foreign and are rarely found in the midst of society (Ainiyah, 2013; Hubbi, et al., 2020). Moral decline as a negative impact of globalization, especially the bad influence of gadgets, has not only afflicted adults, but also elementary school students. The age of the foundation that affects the life of the nation in the future. As stated by Witarsa et al (2018) in their research results which show that gadgets not only affect the mindset or behavior of adults, but also affect the behavior of children, especially elementary school (SD) students, gadgets greatly affect the development of elementary school students, especially development in social interaction. Due to dependence on gadgets, children can develop into antisocial personalities.

This was also obtained by researchers when conducting observations at SDN 19 Rabangodu Utara, Bima City, where most of the fifth grade students were good at accessing 
information instantly by utilizing advanced technology devices such as gadgets to access various information, connect with others and play online games through Internet. As a result of the ease of technology, students become spoiled and rarely read books. Another impact of technology is that students lack empathy for others, this can be seen when one student needs an eraser in the form of an eraser, other students who see this actually hide the eraser and don't want to lend it. Another incident is that students like to litter and ignore the trash that is nearby, this shows students have antipathy or tend to be indifferent to the cleanliness of the surrounding environment. Another negative impact of technology is that students' discipline and honesty have also decreased.

Character education in children is a very important foundation in building personality both during development and for the future (Izzati, et al., 2019). One of the educational factors that play a very important role is the educator, who will teach and be an example for his students. Things that should not be eroded by the times are the cultivation of good character in educating students, including what must be prevented is acts of violence against students, maybe it can happen in the world of education, both by educators and fellow students (Arsyah, et al. al., 2019).

Handling the collapse of the character is to eliminate or improve the factors that cause it. One solution to foster good character is through character education. According to Zubaedi (2011) character can be referred to as a person's identity that has been formed in the process of life by a number of ethical values he has, in the form of his mindset, attitude, and behavior. According to Daryanto \& Darmiatun (2013), character education is a variety of efforts carried out by various school personnel, even those carried out in collaboration with parents and community members to help students become individuals with noble character. Character education is very important to be instilled from an early age. . Therefore, every educational unit at the education level, especially the elementary school level, must have commitment and integrity in building the character of the nation's children. One of them is SDN 19 Rabangodu Utara, Bima City.

Even though from initial observations it was seen that some students behaved poorly, SDN 19 Rabangodu Utara Kota Bima still showed various achievements so that they were still trusted by the community. The community does not hesitate to entrust their children to be educated at SDN 19 Rabangodu Utara, Bima City. Based on the results of a preliminary interview with one of the teachers, it was revealed that the obstacles faced in the implementation of character education, namely the habits of students in learning online or online during the Covid-19 pandemic were carried away during offline learning. So the school must again aggressively instill character values that have previously been applied. This is because at the beginning of the corona pandemic, learning was done online via whatsapp, google classroom, zoom, gmeet and others.

According to Romdloni (2001) teachers were impressed with the learning system at home. Due to an emergency, teachers must use digital learning platforms such as Classroom, Edmodo, Zoom, Gooogle Form, Quizizz, Office 365 and others. Through these facilities, it is hoped that the obstacles of learning from home can be overcome. However, the bold implementation shows surprising learning outcomes. $58 \%$ of children said they were not happy with learning activities at home. $38 \%$ of children said that the school did not have a good program for studying at home. This condition is clear evidence that values-based education is real. Schools should not allow character education for Romdloni (2021).

Many school activities are hampered because of the limitations of not being able to meet face to face. However, at this time the corona pandemic has improved slightly, learning at schools is again carried out offline so that learning can be carried out face-to-face while still adhering to health protocols, namely using masks, washing hands, and maintaining distance. Therefore, SDN 19 Rabangodu Utara, Bima city is again aggressively instilling character values that are priorities to be developed such as being religious, honest, diligent, disciplined and caring/responsible. 
Based on this explanation, it is very important to investigate further about what the implementation of character education at SDN 19 Rabangodu Utara, Bima City is like, and the behavior of students from that school in applying the values of religious character, honesty, perseverance, discipline and caring/responsibility as well as the obstacles that arise. faced in the process of implementing character education.

\section{METHOD}

This type of research uses a mixed method exploratory design with an instrument development model. Creswell (in Samsu, 2017) states that mix methods focus on collecting data (collecting), analyzing data (analyzing), and mixing qualitative and quantitative data in a single study or several research series to obtain comprehensive data. The mixed methods approach in this study combines qualitative research with case study research and quantitative descriptive research with survey methods. A qualitative approach is used to obtain answers to the first and third problem formulations that have been listed in the introduction section, and a quantitative approach is used to obtain answers to the second problem formulation. In this mixed research, researchers need to develop and implement quantitative instruments based on qualitative findings. In this research design, the researcher first reveals the research topic with observations and several participants. The qualitative findings then guide the development of question items and scales for the quantitative survey instrument. In the second phase of data collection, researchers implemented and validated quantitative instruments. In this design, qualitative and quantitative methods are linked through the development of instrument items.

This research was conducted at SDN 19 Rabangodu Utara, Bima City with the subjects in this study namely the principal, vice principal as well as class V teachers, and class IV teachers as well as 85 students in class V at SDN 19 Rabangodu Utara Kota Bima in the academic year 2021/2022. The data collection method used is the method of observation, interviews, questionnaires, and documentation. The instrument used in this research has been through expert judgment. Specifically for statements in the questionnaire, field trials have been carried out on 37 students. The test results of the instrument were analyzed using validity and reliability tests. The data analysis method in this study used two methods, namely the descriptive method using the model developed by Miles and Huberman to process qualitative data and descriptive statistical methods to process quantitative data.

\section{RESULTS AND DISCUSSION}

Schools as educational institutions play an important role in instilling and developing character values in students to suppress the negative effects that are rampant from the will of technology. This is in accordance with the objectives of national education as stated in the Law on the National Education System Number 20 of 2003 article 3, namely that national education functions to develop and shape the character and civilization of a dignified nation in the context of the intellectual life of the nation. One of the elementary schools that implements character education is SDN 19 Rabangodu Utara, Bima City. Based on the vision, mission, and goals of the school as well as the results of interviews with the principal, vice principal, and teachers, it is known that the character values that are a priority to be developed by SDN 19 Rabangodu Utara, Bima City, include religious character values. honest, diligent, disciplined, and caring/responsible. This is in accordance with the opinion of Kesuma, Triatna, \& Permana (2011) which defines character education in a school setting, namely the efforts made by schools in instilling certain reference values which are used as learning that leads to strengthening and developing children's behavior as a whole. The strategy for implementing character education in schools is carried out in several ways, namely integration in self-development programs, and in thematic learning (Daryanto \& Darmiatun, 2013). Therefore, the following is the process of implementing the values of character education carried out at SDN 19 Rabangodu Utara, Bima City. 


\section{Self development activities}

Based on observations and interviews, the integration of character education in selfdevelopment includes routine activities, spontaneous activities, exemplary and conditioning. Routine activities carried out included students being checked for completeness of masks and body temperature and uniformity by security officers and sports teachers. Second, in the classroom before and after learning, the teacher always asks the class leader to lead the prayer. Third, every Friday there will be routine Imtaq activities. Fourth, students of SDN 19 Rabangodu Utara, Bima City held pickets to keep the classroom clean. Fifth, get used to greetings, smiles and greetings when meeting school residents. These activities are said to be routine activities because these activities are carried out by students continuously and consistently at all times so that they become a habit. As stated by Zubaedi (201) that habit is every action and deed of a person that is done repeatedly in the same form so that it becomes a habit so that habit is a very influential factor in character education as stated by Zubaedi (2011) that the character requires habituation in thinking (habits of the mind), habituation in the heart (habits of the heart) and habituation in action (habits of the action). Routine activities temporarily suspended due to the corona pandemic are Monday morning ceremonies, congregational prayers, morning exercises, extracurricular activities, and the Calistung program (Read, write, and count) and literacy.

Based on the results of observations and interviews, spontaneous activities carried out by schools include collecting donations suddenly when a teacher is about to retire and a natural disaster occurs. Other spontaneous activities are giving warnings or sanctions and rewards and advice. The teacher will give a warning spontaneously when he sees students who are late for class, reprimand students who do not pay attention to the teacher who explains the material in front of the class by busy himself or disturbing his friends. Another spontaneous reprimand was given by the teacher when he heard students say rude words, littering, seeing plants in front of the class that looked dry and walking on the stairs in crowds. Special sanctions were also applied by some teachers to students who did not do their homework. These special sanctions include asking students to clean between dirty tables, asking students to come to the front of the class to solve problems from assignments that are not done on the blackboard. Another special sanction is sending students out of class for those who don't do assignments. Reprimands and sanctions are given by the teacher in order to change student behavior for the better. As stated by Wibowo (2012) that a warning or sanction is carried out when the teacher finds out that students have taken actions that are less than commendable and must be corrected right away so that students do not repeat the same thing. it on another occasion.

The form of reward given by the principal and teachers at SDN 19 Rabangodu Utara, Bima City, is giving praise and applause when students experience an increase in their abilities such as increasing reading skills, besides that praise is also given when students get a score of 100 accompanied by applause. Another form of reward is giving prizes to students who excel in the form of new uniforms, stationery, and cash. Giving rewards when students do positive behavior can make students feel happy and proud so that every positive behavior they do can take root in them. As stated by Huda (2010) that the use of positive reinforcement such as giving rewards can encourage and increase student learning motivation, then can control and modify student behavior that is less positive and encourage the emergence of productive behavior.

Although they rarely give praise, high-grade teachers are seen often giving advice to students such as not being lazy to study, lazy to take notes, besides that students are not allowed to take money from underclassmen and have to learn to share with others, especially friends in need. Advising is an effort to provide knowledge to students about good values that they must instill in their minds so that they can apply them in the form of actions in everyday life. As stated by Lickona (1991) that good character is related to knowing the good (knowing 
the good), loving the good (loving the good), and doing the good (acting the good). between knowledge of goodness which then arises the will to do good so that it can do good deeds.

Based on the results of observations and interviews, the exemplary attitude shown by the teacher is wearing the uniform that has been scheduled by the school, and the teacher also goes to school on time. In addition, the teacher will also take the time to perform Duha prayers during breaks, and listen to lecture studies via cellphones when they have free hours. As stated by Suwardani (2020) that a person's character is largely shaped by the people around who are often close to him or who often influence him, which are then imitated to do. This imitation is done through the process of seeing, hearing and following. Therefore, the teacher as a person who often influences students should make himself a good role model for students so that students can imitate him.

Based on the results of observations made by researchers, conditioning which includes facilities and infrastructure that supports the implementation of character education, namely there is a reading garden surrounded by green plants, a sink for washing hands in front of the class, long benches containing student works, trash cans located in front of the class. in front of each room including trash cans to separate organic and inorganic waste, clean, neat and fragrant UKS, multiplication number posters attached to each stair, prayer room equipped with Al-Qur'an and mukena as prayer equipment, school walls there are anti-drug slogans, maintain cleanliness, order boards and Asmaul Husna and live pharmacies. Available school facilities and infrastructure will support character education. As revealed by Zubaedi (2011) that the school environment is one of the factors that influence character education. In addition, according to Darmayanti \& Wibowo (2014: 229) that character education needs to be supported by knowledge of character and management of supporting facilities.

\section{Integrating character values in thematic learning}

This is done by the teachers of SDN 19 Rabangodu Utara, Bima City through a lesson plan in the form of a syllabus and lesson plans in which character values are included. According to the acknowledgment of the Deputy Head of Sector as well as the fifth grade teacher in the interview that it is appropriate for character values to be included in the syllabus and lesson plans because the school has implemented the 2013 curriculum which has the main goal of character development. In addition, based on observations and interviews, the teacher also includes character values in the learning process. In the learning process, the teacher uses discovery learning. The methods, media and learning resources used by the teacher vary according to the content of the material being taught. Teachers carry out active learning that requires students to be active, diligent in learning and focus on learning, and teachers will help students who have difficulty implementing character values.

Inclusion of character values in lesson plans and learning processes is very important to do because the 2013 curriculum is a curriculum that emphasizes the development of student character. This is in accordance with the Regulation of the Minister of Education and Culture No. 64 of 2013, concerning Content Standards for Primary and Secondary Education, Article 1 paragraph 1, confirms that the Content Standards for Primary and Secondary Education, hereinafter referred to as Content Standards, cover the minimum material scope and minimum competency level to achieve minimum graduate competence at certain levels and types of education. . Competencies that must be achieved by students at the elementary school level include spiritual attitudes, social attitudes, knowledge, and skills. Half of the competencies that must be achieved, namely spiritual competence and social competence are related to character values. So that the planning and implementation of learning must include character values.

After knowing the process of implementing the values of character education carried out at SDN 19 Rabangodu Utara, Bima City, then it is necessary to know the behavior of students in applying religious values, honesty, perseverance, discipline and caring/responsibility at the school as a form of reaction or output for the cultivation of values. 
-character value that has been applied. This is because character education plays an important role in shaping student behavior. The quality of character education in a school can be seen from the student's behavior which is reflected in everyday life. This is as the results of research conducted by Sari (2017), that there is an influence of character education on student behavior. After distributing the questionnaire and the data analysis stage to the class $\mathrm{V}$ students, totaling 85 students, the following results were obtained.

The behavior of students in applying character values (religious, honest, diligent, disciplined, and caring/responsible) tends to be in the sufficient category. Overall student behavior was in the good category as many as 18 people $(21.18 \%)$, while in the sufficient category as many as 52 people $(61.17 \%)$ and in the less category as many as 15 people (17.65\%). So it can be concluded that the behavioral tendencies of SDN 19 Rabangodu Utara students in applying character values are in the sufficient category. The behavior of students in applying character values consists of 5 characters, namely religious, honest, diligent, disciplined, and caring/responsible. The following is a detailed description of student behavior.

\section{Religious}

Religious value data was obtained through a questionnaire consisting of 4 items with a total of 85 students as respondents. There are 4 alternative answers with provisions for positive statements the answer 'Always' is given a score of 4, 'Often' is given a score of 3 , 'Rarely' is given a score of 2, and 'Never' is given a score of 1 . What religious characters do students most often and rarely do as presented in the following picture.

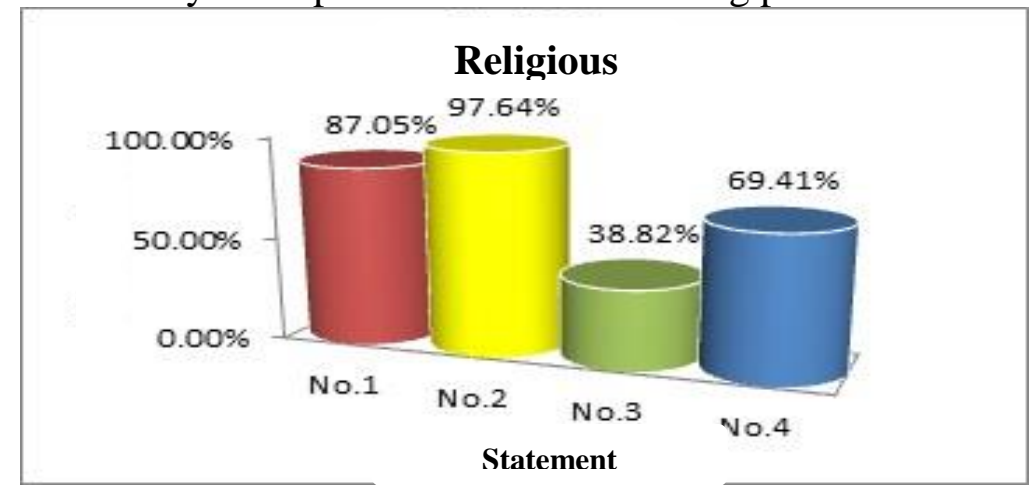

Figure 1. Percentage of Statements of Religious Behavior of SDN 19 Rabangodu Utara students, Bima City

Figure 1 presents data on the religious behavior of students at SDN 19 Rabangodu Utara, Bima City. The highest percentage value is in item number 2 of $97.64 \%$. The point of the statement is to participate in imtaq activities on Friday for those who are Muslim. Item number 1 has a percentage value of $87.05 \%$. The point of the statement is to pray before after studying. Item number 4 has a percentage value of $69.41 \%$. The point of the statement is to greet and give greetings to all school residents when they meet. While the statement with a low percentage is item number 3 , which is $38.82 \%$. The point of the statement is to provide assistance to friends who need help without discrimination based on religion. This percentage indicates that the religious value at SDN 19 Rabangodu Utara needs to be improved again.

Determination of the tendency of variables based on the empirical mean value of the religious character value variable is 13.22 . The standard deviation is 1.923 . From the above calculations, it can be categorized into 3 classes, namely good if $X 15.1$, sufficient if $11.2 \mathrm{X}<$ 15.1 and less if $X<11.2$. Based on these calculations, it can be seen that the tendency of students' religious behavior in the good category as many as 12 people (14\%), while in the sufficient category as many as 56 people $(66 \%)$ and in the less category as many as 17 people (20\%). So it can be concluded that the tendency of religious behavior of students at SDN 19 Rabangodu Utara is sufficient. 


\section{Honest}

Honest value data was obtained through a questionnaire consisting of 3 items with a total of 85 students as respondents. There are 4 alternative answers with provisions for positive statements the answer 'Always' is given a score of 4, 'Often' is given a score of 3, 'Rarely' is given a score of 2, and 'Never' is given a score of 1 . Based on student questionnaire data, the highest score was 12 and the lowest score is 5. The results of the Mean (M) analysis are 13.22; The median (Me) is 9.29; The mode (Mo) is 9 and the Standard Deviation (SD) is 1.610. Based on the analysis of the statement item data, it can be obtained data about what honest character behaviors are most often and least often done by students as presented in the Figure 2.

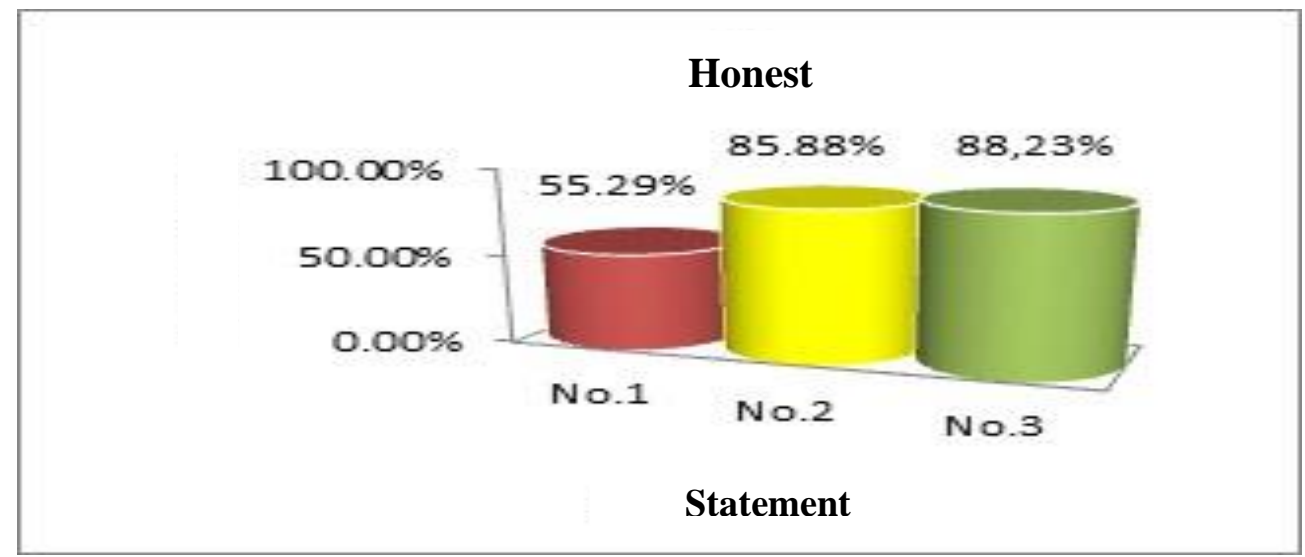

Figure 2. Percentage of Statements of Honest Behavior of Students at SDN 19 Rabangodu Utara, Bima City

Figure 2 presents data on the honest behavior of students at SDN 19 Rabangodu Utara, Bima City. The highest percentage value is in item number 3 of $88.83 \%$. The item in the statement is to pay for food purchased at the school canteen. Followed by a fairly high percentage value also contained in item number 2 of $85.88 \%$, namely telling the truth and returning something that does not belong to him, while the statement item with a low percentage is item number 1 , which is $55.29 \%$. The point of the statement is not asking friends for answers during the test. This percentage indicates that the value of honesty at SDN 19 Rabangodu Utara needs to be increased again.

Determination of the tendency of variables based on the empirical mean value of the honest character value variable is 9.29. The standard deviation is 1.610 . From the above calculation, it can be categorized into 3 classes, namely good if X 10.9, sufficient if $7.6 \mathrm{X}<$ 10.9 , and less if $X<7.6$. Based on these calculations, it can be seen that the tendency of honest behavior of students in the good category is 18 people $(21 \%)$, while in the sufficient category as many as 53 people (62\%) and in the less category as many as 14 people (17\%). So it can be concluded that the tendency of honest behavior of students at SDN 19 Rabangodu Utara is sufficient.

\section{Persistent}

The data of diligent value was obtained through a questionnaire consisting of 4 items with a total of 85 students as respondents. There are 4 alternative answers with provisions for positive statements the answer 'Always' is given a score of 4, 'Often' is given a score of 3 , 'Rarely' is given a score of 2, and 'Never' is given a score of 1 . Based on student questionnaire data, the highest score was 16 and the lowest score is 6 . The results of the Mean (M) analysis are 11.81; The median (Me) is 11.00; The mode (Mo) is 11 and the Standard Deviation (SD) is 1.855 . Based on the analysis of the statement item data, it can be obtained data about what honest character behaviors are most often and least often done by students as presented in the Figure 3. 


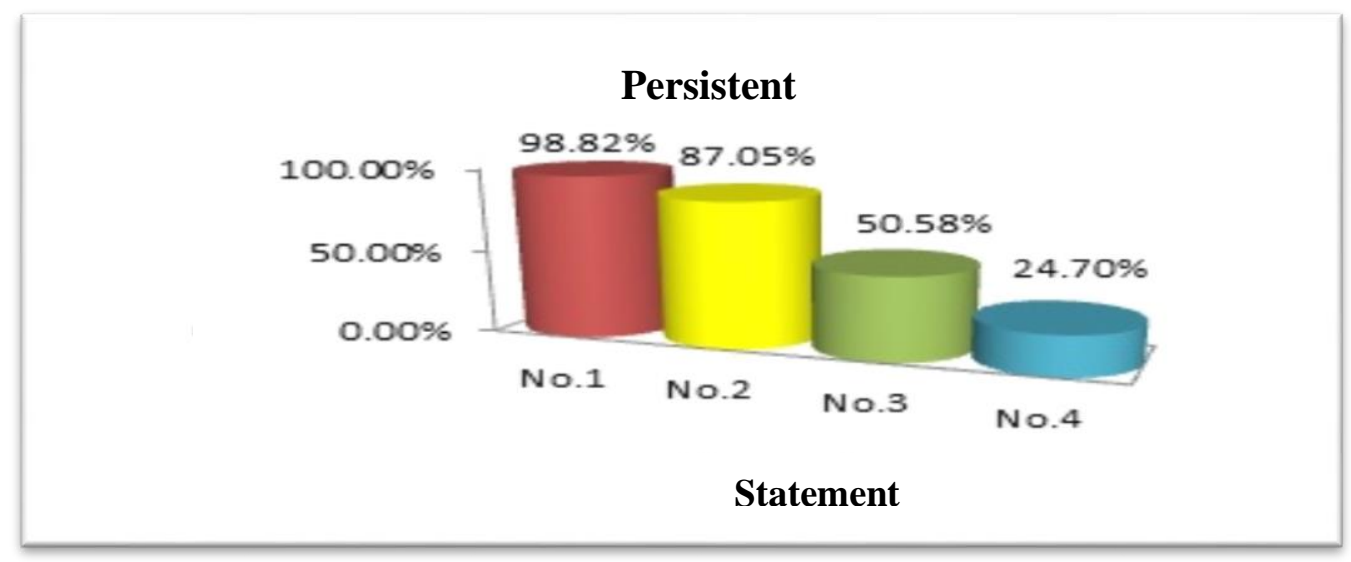

Figure 3. Percentage of Statements of Diligent Behavior of Students at SDN 19 Rabangodu Utara, Bima City

Figure 3 presents data on the diligent behavior of students at SDN 19 Rabangodu Utara, Bima City. The highest percentage value is in item number 1 of $98.82 \%$. The statement item is doing the task given by the teacher. Followed by a fairly high percentage value also contained in item number 2 of $87.05 \%$, namely listening well to the lessons delivered by the teacher. While the statement item with a low percentage is item number 3 of $50.58 \%$. The statement item is daring to express opinions during discussions and ask the teacher when experiencing difficulties while learning. Furthermore, the statement item with the lowest percentage is item number 4 at $24.70 \%$. The point of the statement is to learn without waiting for parental orders. This percentage indicates that the value of diligent character at SDN 19 Rabangodu Utara needs to be improved again.

Determination of the tendency of the variable based on the empirical mean value of the persistent character variable is 11.81 . The standard deviation is 1.855 . From the above calculation, it can be categorized into 3 classes, namely good if $\mathrm{X} 13.6$, sufficient if $9.9 \mathrm{X}<$ 13.6, and less if $X<9.9$. Based on these calculations, it can be seen that the tendency of diligent behavior of students in the good category is 18 people $(21 \%)$, while in the sufficient category as many as 61 people (72\%) and in the less category as many as 6 people (7\%). So it can be concluded that the tendency of diligent behavior of the students of SDN 19 Rabangodu Utara is sufficient.

\section{Discipline}

Discipline value data was obtained through a questionnaire consisting of 4 items with a total of 85 students as respondents. There are 4 alternative answers with provisions for positive statements the answer 'Always' is given a score of 4, 'Often' is given a score of 3 , 'Rarely' is given a score of 2, and 'Never' is given a score of 1. Based on student questionnaire data, the highest score was 16 and the lowest score is 8 . The results of the Mean (M) analysis are 12.78; The median (Me) is 13.00; The mode (Mo) is 14 and the Standard Deviation (SD) is 2.014. Based on the analysis of the statement item data, it can be obtained data about the behavior of the discipline characters that are most often and least often carried out by students as presented in the figure 4. 


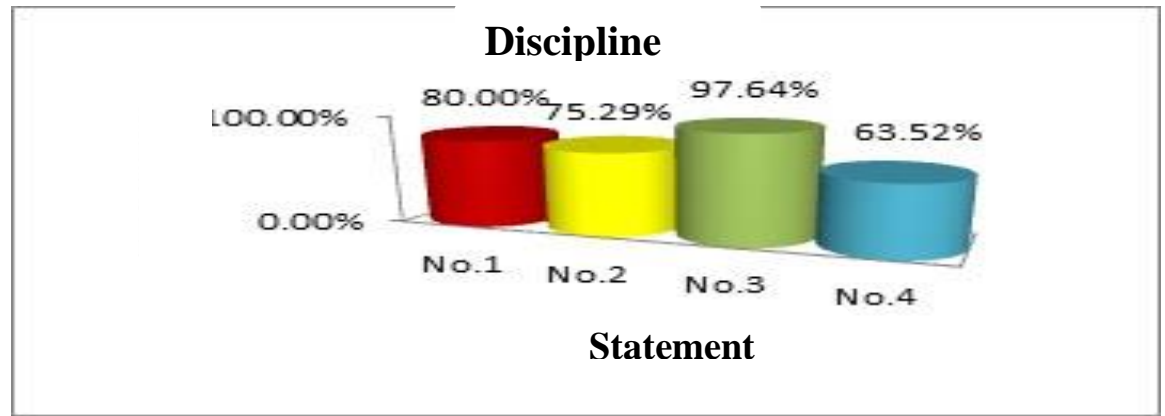

Figure 4. Percentage of Statements of Discipline Behavior of Students at SDN 19 Rabangodu Utara, Bima City

Figure 4 presents data on the disciplinary behavior of students at SDN 19 Rabangodu Utara, Bima City. The highest percentage value is in item number 3 of $97.64 \%$. The point of the statement is to dress neatly and according to schedule. Followed by a high percentage value is also found in item number 1 of $80.00 \%$, namely entering class on time. Furthermore, the percentage value that can be said to be neither low nor high is found in item number 2 of $75.29 \%$, namely carrying out picket duties according to schedule. While the statement item with a low percentage is item number 4 at $63.52 \%$. The point of the statement is to submit assignments on time. This percentage indicates that the value of the discipline character at SDN 19 Rabangodu Utara needs to be improved again.

Determination of the tendency of variables based on the empirical mean value of the discipline character value variable is 12.78 . The standard deviation is 2.014 . From the above calculation, it can be categorized into 3 classes, namely good category if X 14.7, sufficient if $10.7 X<14.7$, and less if $X<10.7$. Based on these calculations, it can be seen that the tendency of student discipline behavior in the good category is 15 people (18\%), while in the sufficient category as many as 57 people $(67 \%)$ and in the less category as many as 13 people $(15 \%)$. So it can be concluded that the disciplinary behavior tendency of the students of SDN 19 Rabangodu Utara is sufficient.

\section{Caring/Responsibility}

The value of caring/responsibility data was obtained through a questionnaire consisting of 9 items with a total of 85 students as respondents. There are 4 alternative answers with provisions for positive statements the answer 'Always' is given a score of 4, 'Often' is given a score of 3, 'Rarely' is given a score of 2, and 'Never' is given a score of 1 . Based on student questionnaire data, the highest score was 36 and the lowest score is 17 . The results of the Mean (M) analysis are 27.26; The median (Me) is 28.00; The mode (Mo) is 29 and the Standard Deviation (SD) is 4,100. Based on the analysis of the statement item data, it can be obtained data about the behavior of the discipline characters that are most often and least often carried out by students as presented in Figure 5.

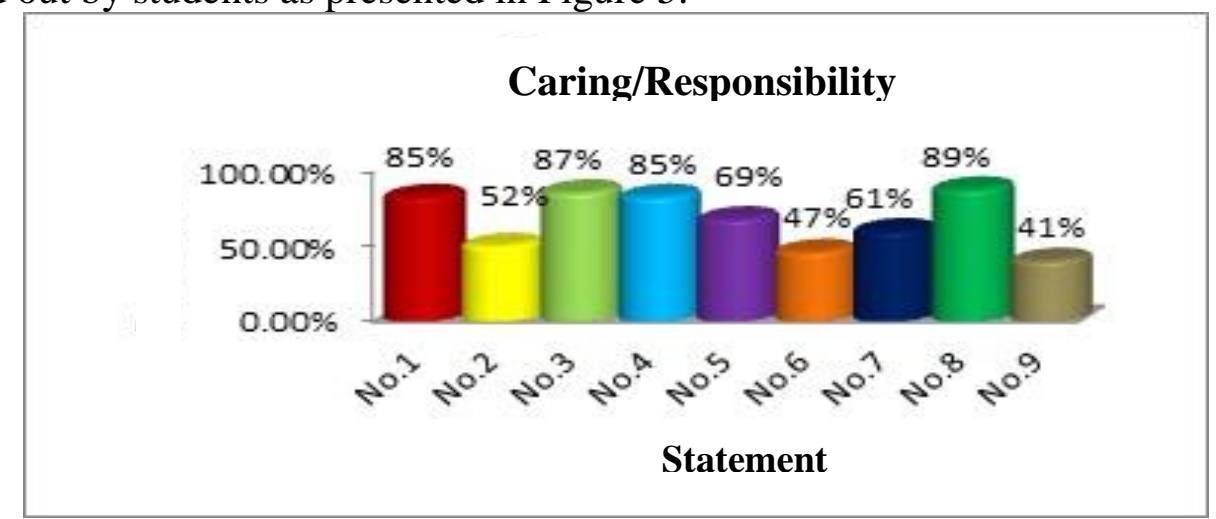

Figure 5. Percentage of Statements of Concerned Behavior/Responsibility of Students at SDN 19 Rabangodu Utara, Bima City 
Figure 5 presents data on the caring/responsible behavior of students at SDN 19 Rabangodu Utara, Bima City. The highest percentage value is in item number 8 at $89 \%$. The point of the statement is to bring your own writing utensils. Followed by a high percentage value is also found in item number 3 by $87 \%$, namely obeying all school rules. The next highest percentage value is found in item number 1 of $85 \%$, namely throwing garbage in its place, with the same percentage value in item number 4 of $85 \%$, which is submitting a permit when not attending school both online and offline. which has a low percentage, there are 4 items, namely numbers 2,5, 6, 7 and 9. The percentage of statement item no. 2 is $52 \%$, namely cleaning the bathroom after using it (flushing the toilet with water until it is clean after urinating or defecating). The percentage of statement item no.5 is $69 \%$, namely speaking well, politely when meeting with teachers or other friends. Furthermore, the percentage of item number 6 is $47 \%$, namely watering the plants in front of the class. The percentage of statement item no.7 is $61 \%$, which is the courage to admit mistakes and immediately apologize. Finally, the percentage of statement item no.9 is $41 \%$, which is helping the teacher to erase the blackboard. This percentage indicates that the value of caring/responsible character at SDN 19 Rabangodu Utara needs to be improved again.

Determination of the tendency of the variable based on the empirical mean value of the caring/responsible character value variable is 27.26 . The standard deviation is 4.100 . From the above calculation, it can be categorized into 3 classes, namely good category if $X 31.3$, enough if $23.2 X<31.3$, and less if $X<23.2$. Based on these calculations, it can be seen that the tendency of caring/responsible behavior of students in the good category is 15 people (20\%), while in the sufficient category there are 53 people (62\%) and in the less category as many as 17 people (20\%). So it can be concluded that the tendency of caring/responsible behavior of students at SDN 19 Rabangodu Utara is sufficient.

The following is a comparison of the results from the implementation process of the five character values that are a priority for SDN 19 Rabangodu Utara, Bima City, as follows.

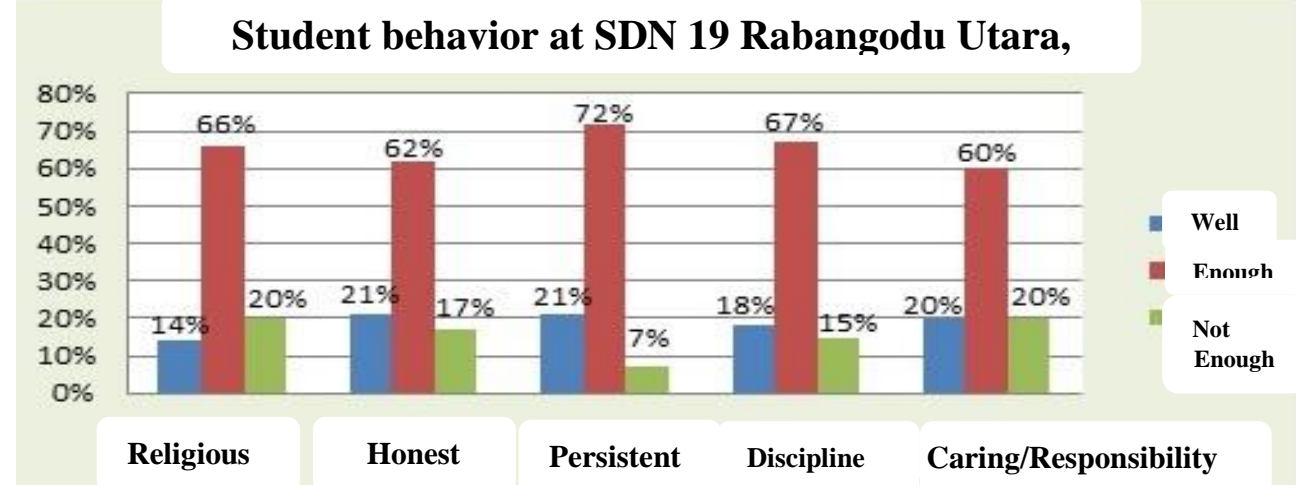

Figure 6. Comparison of Student Behavior in Applying Character Values at SDN 19 Rabangodu Utara, Bima City

After knowing the behavior of students in applying the values of religious character, being honest, diligent, disciplined, and caring/responsible, then we will discuss the obstacles experienced by SDN 19 Rabangodu Uatara, Bima City in implementing character education. Based on the results of the interview, it can be seen that the obstacles faced by SDN 19 Rabangodu Utara, Bima City, are as follows:

Based on the findings during observations and interviews, it can be seen that the obstacles faced by schools in implementing character education are the lack of attention from some parents to students, online habits like playing gadgets and watching TV, and lack of room infrastructure. Efforts made by schools to overcome this obstacle are by providing motivation to students and paying more attention and establishing communication with parents so that they pay more attention to students and control the habits of students who like to play gadgets and watch TV at home. For the problem of lack of room infrastructure, the principal has informed the education office regarding this so that rooms in the school can be 
added, especially classrooms so that learning activities take place effectively and the implementation of character education is not hampered.

In essence, any obstacles in the implementation of character education in schools must be overcome immediately so that the implementation of character education is not disrupted because character education is very important to foster students to have noble character to overcome the negative effects of globalization. As revealed by Fitri (2014: 25) and (Ramdani et al., 2021) that the purpose of character education is to form, instill, facilitate, and develop positive values in children so that they become superior and patient individuals so they can think wisely to respond negative effects of globalization.

Furthermore, in strengthening the implementation of character education in elementary schools, it is necessary to measure. The measurement of student character values can be used by multiple methods and multi-instruments (Setiawan et al., 2021). The methods include observation, daily journals, anecdotal records, and self-assessments (Setiawan \& Tumardi, 2019). The measurement results can be used to strengthen and evaluate the implementation of character education values at SDN 19 Rabangodu Utara, Bima City. In addition, SDN 19 Rabangodu Utara Kota Bima can use experiential learning strategies to improve student character strengthening and reduce academic cheating, where experiential learning defines experience as an element of knowledge formation in the learning process. (Darmiany et al., 2021).

\section{CONCLUSION}

Based on the results of research and discussion of the implementation of character education at SDN 19 Rabangodu Utara, Bima City, the following conclusions were obtained: (1) The process of implementing character education values carried out at SDN 19 Rabangodu Utara, Bima City through self-development activities (routine activities, spontaneous activities, exemplary and conditioning) and integration in thematic learning (syllabus and lesson plans and the learning process). (2) The behavior of students in applying character values (religious, honest, diligent, disciplined, and caring/responsible) is in the sufficient category as many as 52 people $(61.17 \%)$. The rest in the good category as many as 18 people $(21.18 \%)$, and in the less category as many as 15 people $(17.65 \%)$. (3) Obstacles faced by schools in the process of implementing character education values include the lack of attention from some parents to students, the habits of online students who like to play gadgets and watch TV, and lack of room infrastructure.

\section{RECOMMENDATION}

The school is expected to increase the commitment and cooperation of all school members to continue to maximize the development of character values in students so that character education in schools can be maintained and improved again. Especially in developing students' character on the value of religious character, namely in terms of providing assistance to friends who need help without discriminating based on religion. On the value of honest character in terms of not asking friends for answers during the test. On the value of diligent character in terms of daring to express opinions during discussions and asking the teacher when having difficulties while studying and studying without waiting for parental orders, collecting assignments on time on the value of disciplined character, and on the value of caring/responsible character, namely in terms of cleaning the bathroom. after using it (flushing the toilet with clean water after urinating or defecating), speaking well, politely when meeting the teacher or other friends, watering the plants in front of the class and finally helping the teacher wipe the blackboard.

\section{REFERENCES}

Ainiyah, N. (2013). Pembentukan Karakter Melalui Pendidikan Agama Islam. Jurnal AlUlum, 13(1), 25-38. 
Anwar, C., Saregar, A., Hasanah, U., \& Widayanti, W. (2018). The effectiveness of islamic religious education in the universities: The effects on the students' characters in the era of industry 4.0. Tadris: Jurnal Keguruan Dan Ilmu Tarbiyah, 3(1), 77-87.

Darmayanti, S. E., \& Wibowo, U. B. (2014). Evaluasi Program Pendidikan Karakter Di Sekolah Dasar Kabupaten Kulon Progo. Jurnal Prima Edukasia, 2(2), 223. https://doi.org/10.21831/jpe.v2i2.2721

Darmiany, Widiada, I. K., Nisa, K., Maulyda, M. A., \& Nurmawanti, I. (2021). Strengthening Character Value Based on Experiential Learning to Reduce Student Academic Cheating Behavior. Premiere Educandum: Jurnal Pendidikan Dasar Dan Pembelajaran, 11(1), 135. https://doi.org/10.25273/pe.v11i1.8810

Daryanto, \& Darmiatun, S. (2013). Implementasi Pendidikan Karakter di Sekolah (1 ed.). Yogyakarta: Dava Media.

Fitri, A. Z. (2014). Pendidikan Karakter Berbasis Nilai \& Etika Di Sekolah (1 ed.). Jogjakarta: AR-Ruzz Media.

Hubbi, U., Ramdani, A., \& Setiadi, D. (2020). Integrasi Pendidikan Karakter kedalam Pembelajaran Pendidikan Agama Islam dan Pendidikan Kewarganegaraan di Era Milenial. JISIP (Jurnal Ilmu Sosial dan Pendidikan), 4(3).

Huda, N. (2010). Strategi Pembelajaran. Jakarta: PT. Multi Kreasi Satu Delapan

Izzati, U. A., Bachri, B. S., Sahid, M., \& Indriani, D. E. (2019). Character Education: Gender Differences In Moral Knowing, Moral Feeling, And Moral Action In Elementary Schools In Indonesia. Journal for the Education of Gifted Young Scientists, 7(3), 547-556.

Kesuma, D., Triatna, C., \& Permana, J. (2011). Pendidikan Karakter Kajian Teori dan Praktik di Sekolah (1 ed.). Bandung: PT Remaja Rosdakarya.

Lickona, T. (1991). Educating For Character: How Our School Can Teach Respect . New York: Bantam Books.

PERMENDIKBUD No. 64 tahun 2013 tentang Standar isi Satuan Pendidikan Dasar Dan Menengah. Jakarta : Kementrian Pendidikan dan Kebudayaan

Ramdani, D. R., Setiawan, H., \& Mataram, U. (2021). Analisis Muatan Nilai Karakter Pada Buku Guru Dan Siswa Kurikulum 2013 Kelas V Semester 2 Sekolah Dasar An Analysis Of Character Values In The Textbooks Of Teachers And Students Of The Fifth Grade Of Elementary School On The. 1(3), 207-217.

Ramdhan Witarsa, Rina Sri Mulyani Hadi, Nurhananik, N. R. H. (2018). Pengaruh Penggunaan Gadget Terhadap Kemampuan Interaksi Sosial. Pedagogik, VI, No. $1(1), 9-20$.

Samsu. (2017). Metode penelitian: teori dan aplikasi penelitian kualitatif, kuantitatif, mixed methods, serta research \& development. In Diterbitkan oleh: Pusat Studi Agama dan Kemasyarakatan (PUSAKA).

Sari, 2017. "Pengaruh pendidikan terhadap perilaku siswa di SMP Mamba'ul Hisan Gandusari Kabupaten Blitar". Skripsi. Tulungagung: IAIN Tulungagung.

Setiawan, H., \& Tumardi, T. (2019). Pengembangan Instrumen Asesmen Kompetensi pada Ranah Afektif di Sekolah Dasar. Musamus Journal of Primary Education, 2(1), 112. https://doi.org/10.35724/musjpe.v2i1.1944

Setiawan, H., Nurhasanah, N., Umar, U., Nurmawanti, I., \& Fauzi, A. (2021). Instrument Development on Character Value Assessment at Grade IV Elementary School Students. Proceedings of the 2nd Annual Conference on Education and Social Science (ACCESS 2020), 556(Access 2020), 470-475. https://doi.org/10.2991/assehr.k.210525.130

Suwardani, N. (2020). "Quo Vadis" Pendidikan Karakter: dalam Merajut Harapan Bangsa yang Bermanfaat (1 ed.). Bali: UNHI Press.

Undang-Undang No. 20 tahun 2003 tentang Sistem Pendidikan Nasional. Jakarta : Sekretaris Negara Republik Indonesia.Darmiany, Widiada, I. K., Nisa, K., Maulyda, M. A., \& 
Nurmawanti, I. (2021). Strengthening Character Value Based on Experiential Learning to Reduce Student Academic Cheating Behavior. Premiere Educandum: Jurnal Pendidikan Dasar Dan Pembelajaran, 11(1), 135. https://doi.org/10.25273/pe.v11i1.8810

Wibowo, A. (2012). Pendidikan Karakter Strategi Membangun Karakter Bangsa. Yogyakarta: Pustaka Belajar.

Zubaedi. (2011). Desain Pendidikan Karakter: Konsepsi dan Aplikasinya dalam Lembaga Pendidikan (1st ed.). Kencana Prenada Media Group.

Romdloni, M. A. (2021). Pendidikan karakter masa pandemi covid-19 di SD. IJPE: Indonesian Journal of Primary Education, 5(1), 1-12. 